\title{
Relasi Hukum Dan Moral Perspektif Imperative Categories
}

\author{
Ridwan \\ Sekolah Tinggi Ilmu Hukum Muhammadiyah Bima \\ (ridwan@stihm-bima@ac.id)
}

Abstrak: Scopenhauer menyatakan, seseorang akan tetap terlihat kanak-kanak sebelum memahami filsafat Kant, hal ini menunjukkan begitu besar dan pentingnya pemikiran Kant dalam membentuk pengetahuan modern berserta impilkasinya, termasuk pergeseran pola relasi hukum dan moral. Tulisan ini bertujuan membahas permasalah relasi hukum dan moral dalam perspektif imperative Categories Immanuel Kant. Menggunakan jenis penelitian doktrinal, pendekatan filosofis. Hasil analisis menunjukan relasi hukum dan moral dalam pemikiran Immanuel Kant berada dalam bentuk relasi independen-dialog, dimana hukum dan moral terpisah akan tetapi sederajat, baik pada level objek, sumber, metodelogi, dan tujuan.

Kata Kunci: Relasi., Hukum., Moral, Imperative, Categories.

Abstract: $\quad$ Scopenhauer states, a person will still look childish before understanding Kant's philosophy, this shows the great importance and importance of Kant's thought in shaping modern knowledge and its implications, including shifting patterns of legal and moral relations. This paper aims to discuss the problem of legal and moral relations in the perspective of Immanuel Kant's imperative Categories. Using a type of doctrinal research, a philosophical approach. The results of the analysis show that the legal and moral relations in Immanuel Kant's thought are in the form of an independent-dialogue relationship, where law and morals are separate but equal, both at the level of object, source, methodology, and goal.

Keywords: Relations., Law., Moral, Imperative, Categories 


\section{PENDAHULUAN}

Pemikiran hukum terus mengalami perubahan, searah dengan ritme perubahan pengetahuan pada umumnya, mulai dari bercorak corak metafisik-kosmologis, yang merupakan warna alam pikir masyarakat Yunani Kuno pra Trio Yunani, yang juga skeptic terhhadap pengetahuan yang objektif dan rasional, maka orintasi umum pemikiran pada masa itu adalah berorientasi pada upaya survival atas kekejaman alam. Selanjutnya pemikiran manusia terus mengalami perubahan yang sangat signifikan ketika muncul trio Yunani yaitu Socrates, Plato dan Aristoteles, yang menyangkal dominasi pemikiran sebelumnya, hukum dan pengetahuan pada umunya tidak lagi dilihat sebagai gejala kemarahan alam, akan tetapi harus dilihat sebagai sesuatu yang rasional yang harus ditemukan oleh manusia, corak pemikiran seperti menunjukan corak yang metafisik naturalis. Pemikiran sleanjutnya adalah yaitu corak metafisik religious atau sebutan lainnya skolastik, dimana St. Thomas Aquinas dalam karyanya Summa Theologica, sebagai tokoh sentral, dimana hukum bersumber dari ajaran ilahi, dan di tujukan untuk pengabdian untuk ilahi. ${ }^{1}$

Selanjutnya corak pemikiran rasional-objektif, yaitu pemikiran yang menjadikan rasio dan pengamatan empris sebagai objek seklaigus ukuran kebenaran, sembari menolak realittas metafisik sebagaimana yang di usung pada era-era sebelumnya, karena dianggap spekulatif, pemikiran spekulatif penuuh dengan motif dan tensenis subjektif, karena itu tidak pada diajaidkan sebagai penegathuan umum termasuk juga untuk hukum.

Momentum perubahan itu yang sangat signifikan terjadi di masa ketiga copernikan dan Galileo mendobrak dominasi pemikiran lama Aristotelian yang heliosentris yang digantikan dengan geosentrisme.

Salah satu pemikir yang juga merubah haluan pandangan tentang sains dan metafiska adalah Immanuel kant yang membeda memtafisika menajdi metafisika kuno dan metafiiska sebagai sains, yang memisahkan wilayah fenomena dan noumena. Pemikiran kant itu menjadi pijakan awal dari para pemikir positivisme pada umumnya dan positivisem hukum khususnya.

Pemikiran Immanuel Kant merupakan usahanya untuk mendamaikan konflik berkepanjangan rasionalisem dan kelompok empriisme. Dikemudian hari pemikiran Kant kemudian menjadi cikal bakal

\footnotetext{
1 Pemikiran abad pertenganhan yang bercorak metafiisk-religius ini dikemudian hari di gugat oleh Ockham yang menolak konsep iman sebagai realitas. Ocham menganggap model Aquinas sebagai sesuatu yang sudah usang yang harus segera diganti oleh kekuatan nalar manusia sebagai dasar menentukan ilmu pengetahuan, Pemikiran Ockham ini kemudian mendorong atau menjadi semacam prakondisi lahirnya gerakan reformasi dilembaga gereja, yang kemudian lahir Kristen protestan dan empirisme yang merupakan cikal bakal ilmu pengetahuan modern pada akhir abad XV hingga XVIII. Lihat T.M. Soerjanto Poespowardojo \& Alexander Sera, Filsafat Ilmu Pengetahuan: Hakikat Pengetahuan, Kritik Terhadap Visi Positivisme Logis Serta Implikasinya, (Jakarta: Kompas, 2015), hlm. 136.
} 
kemapanan positivisme. ${ }^{2}$ Kant jugalah filsuf pertama yang membersihkan metafisika dari sains, termasuk memisahkan wilayah moral dan wilayah hukum, yang kemudian diikuti oleh para pemikir positivisme lainnya, mulai dari yang empiris/klasik dan positivisme logis/murni, yang banyak diadopsi oleh Negara-negara modern hingga kini.

Menelaan pemikiran Immanuel Kant menjadi penting disebbkan oleh bebrapa hal: pertama, pemikiran kant menjadi cikal bakal kemapana positiivsme, yang juga memunculkan varian aliran pemikiran lainnya yang mapan serta mendominasi alam pikir masyarkat modern hingga kini; kedua, klaim positivisme yang rasional-objektif, menyebabkan terlepasnya nialia-nilai transeden termasuk agama-tuhan serta juga moral sebagai bagaian dari unsure yang mem=validasi hukum; ${ }^{3}$ Ketiga, Ketertutupan hukum terhadap moralitas yang dikibarkan oleh penganut legalisme, ${ }^{4}$ legal positivisme, ataupun reinerechtslehre, tidak

\footnotetext{
2 dan positivisme sendiri mendapat kritik tajam dari bebrgai pemikiran lain, karean di anggap tidak mampu mengatasi masalah, bahkan dituduh sebagai penyebab masalah masyarakat modern. Salah satu pemikiran yang fokal mengkritik positivisme adalah Husserl dengan fenomenologinya, pemikiran fenomenologi Husserl melahirkan juga Neo-Kantian, dan mengkondisikan lahirnay aliran filsafat lingkaran wina (positivisme kalsik), dan hermeneutika (aliran marbur, Hans Kelsen, Baden, dll. Lihat T.M. Soerjanto Poespowardojo \& Alexander Sera, Filsafat Ilmu Pengetahuan: Hakikat Pengetahuan, Kritik Terhadap Visi Positivisme Logis Serta Implikasinya, (Jakarta: Kompas, 2015), hlm. 138139.

3 Klaim netralitas atau objektiiftas positive logi tersebut mendapat reaksi dari atau gugutan dari aliran Frankfur Jerman atau aliran teori kritis, menurut aliran ini tidak ada kebenaran ilmih yang melulu spekulatif atau semata-mata empiris. Klaim netralitas dan objetifitas ilmu pengetahuan oleh empirisme atau positivisme logis bersifat manipulative untuk menutup kedok modernisme yang sesungguhnya menjadi pemicu patologi sosial, sebagai aimplikasi atas pendewaan rasio instrumental. Jurgen Habermas sebagai generasi kedua Mazhab Framkfurt juga menggugat kalim netralitas dan objetifitas ilmu pengetahuan oleh empirisme atau positivisme logis, bagi Habermas pengetahuan tercakup kepentingan dalam semua jenis ilmu pengetahuan: 1) ilmu empiris-analitis tercakup tercakup kepentingan teknis, kemampuan membuat prediksi berdfasarkan hukum-hukum induktif. Ungakapan teori bagaiman rasionalitas di gunakan secara tepat untuk mengusasi alam bagi pemenuhan kepentingan manusia; 2) ilmu historis-hermeneutis tercakup kepentingan praktis, yakni kemampuan menjalin hubungan-hubungan dnegan masyarakat melalui interpretasi atas realiats sosial. Kepentinag praktis merupakan ungkapan teori menegnai bagaimana rasioanlitas di gunakansecara pantas dan patut untuk meningkatkan integrasi sosial; 30 ilmu pengetahuan reflektif tercakup kepentingan emansipatoris, yakni priabdi dalam keharusan-keharusan (hukum) alam atau bduaya, kepentingan emansipatoris merupakan ungkapan teori mengenai kebebasan dan pembebasan sebagai proses otonomi moral atau dekolonisasi budaya. Lihat T.M. Soerjanto Poespowardojo \& Alexander Sera, Filsafat Ilmu Pengetahuan: Hakikat Pengetahuan, Kritik Terhadap Visi Positivisme Logis Serta Implikasinya, (Jakarta: Kompas, 2015), hlm. 184.

${ }^{4}$ Legalisme menurut Jurgen Habermas, tidak memberikan motif moral apapun kepada subyek hukum. Dalam wawasan legalisme, hukum modern hanya melindungi kecendErungan pribadi, didalam batas-batas yang sudah ditentukan secara formal. Akibatnya bukan dispensasi jahat yang di beri sanksi, melainkan prilaku yang menyimpang
} 
hanya memunculkan teriakan ketidakadilan disana-sini, akan tetapi juga hukum tampil dengan wajah totalitarian ${ }^{5}$ (versi podgorecki), ataupun hukum represif ${ }^{6}$ (versi Nonet Selznick), bahkan hukum sebagai alat kejahatan (versi Roni Nitibaskara). Dalam konteks kelndonesia, wajah hukum yang minus moral seperti itu menurut Khudzaifah Dimyati disebut sebagi hukum yang miskin idiologis ke-Indonesiaan ${ }^{7}$ karena itu ahisotris. ${ }^{8}$

dari norma (Jurgen Harbemas, Rasio dan rasionalitas masyarakat, terjemahan dari Theorie Des Kommunikative handles oleh Nurhadi, (Bantul: Kreasi Wacana, 2012), hlm. 319.

5 Hukum totalitarian, adalah suatu system hukum dengan ciri : pertama, substansi hukumnya berisi peraturan yang mengikat sepihak dan materinya berubah-ubah sesuai inginan yang bersifat arbitrer sang penguasa. Kedua, aturan hukum diapakai sebagai kedok dengan cara yang "lihai" untuk menutupi intervensi kekuasaan yang berlebihan. Ketiga, "penerimaan" masyaratakat terhadap hukum berjalan dalam kesdaran palsu. Keempat, sanksi-sanksi hukum potensil menimbulkan keberadaan social (social disintegrasion), dan nihilism social mneybar tak terkendali. Kelima, tujuan akhir hukum adalh legitimasi institusional yang lepas dari persoalan diterima atau tidaknya masyarakat. Urain menyeluruh tentang hukum totalitarian, dapat dibaca dalam Adam Podgorecki \& Oligiati (eds), 1996.

6 Hukum menjadi represif karena ada pemaksaan ketaaan moralitas komunal oleh pengusa. Lihat Philippe Nonet end Philip Selznick, Hukum Responsif, Bandung: Nusa Media, 2010, hlm. 52. Hukum represif memiliki sepuluh ciri yaitu : (1). Ketertiban menjadi tujuan utama hukum (2). Legitimasi atau dasar kekuatan yang mengikatnya adalah kekuasaan Negara, (3). Peraturan-peraturan yang terumus secara rinci bersifat keras (represif) mengikat rakyat tetapi lunak terhadap penguasa. (4). Alasan pembuatanya bersifat ad-hoc sesuai keinginan arbitrer penguasa, (5). Kesempatan bertindak bersifat serba meresap sesuai kesempatan, (6). Pemaksaan serba mencakupi tanpa batas yang jelas, (7). Moralitas yang dituntut dari masyarakat adalah pengendalian diri (8). Kekuasaan menempati posisi diatas hukum, (9). Kepatuhan masyarakat harus tanpa syarat, dan ketikpatuhan dihukum sebagai kejahatan, (10). Partisipasi masyarakat dijinkan lewat penundukkan diri, sedangkan kritik dipahami sebagai pembangkalan (Phillepe Nonet \&phillip Selznick, Law and Society in transition : toward tanggapananive, London: Harper n Row Publisher) lihat juga Yovita A. Mangesti, Bernard L. Tanya, Moralitas Hukum,( Yogyakarta, Genta Publishing, 2014). penjelasan Shaomin Li, Ilan Alon dan Jun Wu melakukan studi atas hubungan antara tipe rezim, korupsi, dan pembangunan ekonomi. Dengan mengambil sampel 158 negara Mereka membedakan tiga jenis rezim, autocracy (dictatorship), anocracy (countries in early stage of democratization), dan mature democracy. Mereka menemukan transisi dari bentuk negara autrokrasi menuju bentuk negara demokrasi maka korupsi cenderung memburuk. Shaomin Li dkk menyatakan, “...We found that when autocratic countries begin democratize, corruption usually gets worse. As the infant democracies mature, corruption decreases. Lihat Shaomin Li, Ilan Alon \& Jun Wu, Corruption May Worsen In Democratizing Economies: But Don't Let It Erode Our Faith In Democracy, Modern China Studies: Norfolk, Vol. 24, Issue. 2 (2017): 184-188.

${ }^{7}$ Hukum pada pada dasarnya memiliki identitas, bahan dari identitas itu adalah ide-ide, nilai-nilai, serta kenyataan hidup, karena itu hukum sesungguhnya memiliki basis sosial tertentu, yang meliputi unsur fisik dan non-fisik, lihat Satjipto Rahardjo, Pendidikan Hukum Sebagai Pendidikan Manusia: Kaitannya dengan Profesi Hukum dan Pemabangunan Hukum Nasional, (Yogyakarta: Genta Publishing, 2009), hlm. 135.

${ }^{8}$ Untuk menjawab persoalan itu Dimyati mengajukan kerangka teoritik ilmu hukum holisitk yaitu paradigma profetik, Kerangka dasar ilmu hukum integrative menurut Khudzaifah Dimyati, 1) memiliki tiga nilai dasar, yaitu humanisasi, liberasi, dan transendensi. 2) secara epsitimologis sumber pengetahuan itu ada 3 yaitu realitas empiris, rasio dan 
Persoalannya seperti apakah relasi hukum dan moral pada pemikrian Immanuel Kant, pertanyaan-pertanyaan ini belum terjawab secara sistimatik akademik, hal ini penting agar kita tidak senantiasa secara a priori menghakimi positivisme (KANT SEBAGAI PERINTISNYA) sebagai sumber pesoalan, apa memang benar kant memisahkan wialayh hukum dan wilayah moral sebagai mana yang dipahami pengemban teoritik positivisme hukum saat ini yang sanngat kokoh menempatkan hukum sebagai norma positivise semata ala kelseninan, atau perintah yang berdaulat ala austinia, dan aturan-aturan ala hartnian.

Hal itulah yang menyebabkan mengidentifikasi pola relasi hukum dan moral dalam pemikiran Immanuel Kant sesungguhnya tidak boleh dianggap sederhana, sebab kant diangap sebagao pencetus positivisme, maka untuk menjangkau bentuk relasi itu dalam tulisan ini mencoba meliaht asumsi-asumsi atau argumenatsi kant tentang objek hukum dan moral, sumber, metodelogi dan tujuan dari kedua dispilin, hal ini penting memngingat. Moral merupakan hilir sekaligu hulu dari hokum, Kita tidak sekedar apriori atas pemikiran kant, tanpa mendapatkan penjelasan yang memadaia. Mengingat relevansi pemikiran immaneul kant dalam konteks Negara berkembang seperti Indonesia yang masih transisi atas tujuan hukum, terutama dalam tahap impelentasinya.

\section{METODE}

Tulisan ini menggunakan metode doktorinal atau istilah lainnya berupa jenis penelitian normative, ${ }^{9}$ dimana hukum dimaknai sebagai kumpulan asas-asas, nilai kebenaran dan keadilan. Bila mengikuti pendapat Soejono SoeKanto ${ }^{10}$ maka penelitian ini termasuk dalam penelitian atas asas-asas hukum, sementara kalau mengacu ke Soetandyo

\footnotetext{
wahyu. 3) secara metodelogis, tidak bebas nilai.4) keberpihakan etis. Lihat Khudzaifah Dimyati, Pemikran Hukum: Sebuah Konstruksi Epistomologi dalam Pemikiran Berbasis Nilai Budaya Hukum Indonesia, (Yogyakarta: Genta Publishing, 2014). Sementara Absori menyatakan kerang hukum transeden yang ditawarkan tidak boleh lepas dari idiologi negara berupa pancasila. Lihat Absori, dkk, Transedensi Hukum: Prosepek dan Implemetasi, Yogyakarta: Genta Publishing dan Program Doktor (S3) IImu Hukum SPs UM Surakarta, 2017), hlm. 23.

${ }_{9}$ Penelitian hukum sejatinya merupakan studi interdisipliner, yang tidak bisa di kemas dalam satu atau dua meted khusus.

10 Soejono Soekanto msialnya membagai dua model penelitian hukum yaitu, pertama, peneltian hukum normatif atau penelitian yuridis normatif yang terdiri atas; 1 ) penelitian atas asas-asas hukum, 2) sistematika hukum, 3) taraf sinkronisasi hukum, 4) sejarah hukum, 5) perbandingan hukum. Kedua, adalah penelitian hukum empiris atau sosiologis, yang terdiri atas; 1) penelitian terhadap identifikasi hukum, dan 2) penelitian terhadap efektifitas hukum. Soejono Soekanto, Pengantar penelitian hukum, (Jakarta: Universitas Indonesia, 1981).
} 
Wingjosoebroto, ${ }^{11}$ penelitian ini termasuk penelitian doktrinal yang berupa usaha penemuan asas-asas dan dasar falsafah (dogma atau doktrinal) hukum positif. Dimana hukum dikonsepkan sebagi asas keadilan dalam sistem moral. Pendekatan penelitian menggunakan pendekatan filosofis, sementara sumber data berupa data primer atau kepustakaan. Tekhnik analisa data, setelah data di kategorisasi, sistimatisasi, maka dianalisis dengan mendeskripsikan, dan menginterpretasikan lalu kemudian menarik kesimpulan.

\section{HASIL DAN PEMBAHASAN}

Scopenhauer menyatakan, seseorang akan tetap terlihat kanakkanak sebelum memahami filsafat Kantm, hal ini menunjukan begitu pentingnya konstribusi Immanuel Kant alam sejarah ilmu pengetahun modern. Immanuel Kant disebut sebagai filsuf yang membunuh metafiiska, disebabkan penolakannya atas model pengetahuan klasik yang spekulkatif, pada sisi lain ia juga dianggap sebagai penyelamat metafisika, berkat pemisahan oleh kant pada tempatnya masing-masing wilayah akal teoritis (sains) dan wilayah akal praktis (agama, moral, dan hukum). Pemisahan wilayah disiplin setiap ilmu tersebut membawa implikasi berubahnya bentuk relasi, bila pada pemikiran aliran hukum kodrat ala Yunani klasik yang bercorak naturalis, maupun ala abad pertengahan bercorak religius sama-sama dalam bentuk relasi integrative, maka relasi hukum dan moral pada pemikiran Kant mengalami pergeseran, yaitu dalam pola relasi independen-dialog.

Pemikiran model Kant berupaya memisahkan disiplin suatu objek, sumber, metodelogi dan tujuan pada tempatnya masing-masing, akan tetapi setiap aspek disiplin tersebut tidak otonomi sepenuhnya, terutama sekali dalam mengimplementasikan nilai dari masing-masing disiplin, misalnya saja ketika sesorang menanti hukum (lahirian), karena atas dasar "sesuai kewajiban" disebabkan keharusan legal/yuridis yang memiliki kekuatan paksa, ancaman sanksi yang tegas, hal ini menujukan relasi independen, akan tetapi tetapi saat yang sama ada seseorang selain menaati bentuk legal tadi karena tuntutan keharusan yuridis juga disebkan kesadaran hakiki, "demi kewajiban” (batiniah) hal ini sudah

\footnotetext{
11 Sementara Soetandyo Wingjosoebroto, membagi penelitian hukum ke dalam; pertama penelitian doktrinal. Kedua penelitian nondoktrinal, yaitu penelitian berupa studi-studi empiris untuk menemukan teori-teori mengenai proses terjadinya dan mengenai proses bekerjanya hukum di dalam masyarakat, tipologi penelitian yang terakhir ini sering disebut socio legal research. Soetandyo Wignjosoebroto Soetandyo W, Penelitian Hukum: Sebuah Tipologi, Majalah Masyarakat Indonesia Tahun Ke1, No, 1974, hlm. 4. Lihat, Soetandyo Wignjosoebroto, Hukum: Paradigma, Metode dan Dinamikan Maslahnya, Jakarta: Huma-Elsam, 2002, hlm. 148-152. Lihat juga Soetandyo Wignjosoebroto, Hukum: Paradigma, Metode Dan Dinamikan Maslahnya, (Jakarta: Huma-Elsam, 2002), hlm. 146147.
} 
menunjukan relasi dialog. Untuk dapat memahami pola relasi hukum dan moral dalam pemikiran Immanuel Kant, harus dipahami uraian penjelasan kant tentang aspek objek, sumber, pemisahan disiplin hukum dan moral, serta tujuan, akan kami uraikan secara spesifik relasi setiap aspek.

\section{Objek Hukum dan Moral}

Aspek objek, jelas memperlihatkan relasi independen, sekaligus corak pemikiran filsafat antroposentris (fisik), hal ini tergambar jelas dalam pembagiannya tentang dua sudut pandnag tentang metafisika, yang kemudian di jelaskan lebih lanjut dalam buku kritik akal teoritis dan akal praktis.

Kant membagi metafisika dalam dua pengertian, yaitu: 1) Metafisika Kuno, yaitu metafiiska yang bercorak "naturalis" sebagaimana yang pahami oleh para pemikir hukum kodrat yunani kuno, serta metafisika "spiritualis" yang berjaya di abad pertengahan ala Thomas Aquinas. Kant menganggap dua varian metafisika diatas, sebagai bentuk pengetahuan spekulatif tentang realitas yang supersensibel dan tidak bersyarat, metafisika spekulatif inilah yang dikritik oleh Kant dalam karyanya critique of pure reason); 2) metafisika sebagai sains, yakni infentarisasi seluruh pengetahuan yang diperoleh dengan akal budi murni dan tertata secara sistematis. Sebuah sistem pengetahuan a priori yang tercipta dari konsep-konsep belaka. Metafisika sebagai sains inilah yang ingin dibangun oleh Kant. Baik metafisika alam, yang berisi seluruh prinsip a proriari tentang "apa" dan; maupun metafisika moral, yang berisi seluruh prinsip a priori tantang "apa yang seharusnya". ${ }^{12}$

Bagi Kant, objek dari ilmu pengetahuan pada umunya haruslah objektif, universal, dan rasional, sebaliknya bukanlah spekulasi, yang bersumber dari dogma atau ajaran agama, karenan itu Kant lalu memisahkan objek ilmu alam dan objek hukum serta moral dalam areal yang terpisah, hal ini menunjukan corak pemikiran kant yang antroposentris, dimana Kant menyatakan wilayah fenomena sebagai wilayah ilmu-ilmu alam, yang termasuk dalam pengetahuan Akal teoritis, dan alam noumena yang ada dalam akal praktis yakni wilayah yang memproduksi atau menangkap norma baik norma yang berupa; maxime (isi/moral) yang menurut Kant hanya relevan pada tahap pembuatan hukum (proses legislasi); kedua, bentuk/legal, yang merupakan wilayah legalitas atau hukum.

Pemisahan alam fenomen dan noumena oleh Kant dilatar belakangi oleh keterbatasan alam "rasio murni" (pure reason) sebagai wilayah sains yang tidak mampu menjangkau objek noumena, yaitu dunia think in itself. Menurut Kant, manakala sains dan rasio memasuki

\footnotetext{
${ }^{12}$ Immanuel Kant, Critique of Practical Reason (Yogyakarta: Pustaka Pelajar, 2005), hlm. xii.
} 
wilayah noumena, yang adalah sains akan terjebak, tersesat dan hilang dalamantinomy dan paralogisme. Oleh sebab itu untuk Kant berusaha melindungi noumena diperlukan penggunaan "akal praktis" (practical reason).

Kant menguraikan, ada tiga postulat kategoris yang menjadi dalildalil akal praktis yang keberadaannya harus diterima dan dipercaya kebenarannya, yaitu: 1) kebebasan kehendak (reiheit), yang berisfat $a$ priori dan transendental; 2) immortalitas (unsterblichkeit), berhubungan dengan summum bonum, berupa kebaikan tertinggi (virtue atau highest good); 3) eksistensi Tuhan (das dasein gottes), Tuhan sebagai sumber kebagikan tertinggi, karena itu mempercayai adanya Tuhan merupakan keniscayaan.

Kant juga menguraikan ada tiga prinsip dasar moralitas, yaitu; 1) universalitas; bahwa sutatu tindakan dianggap bernilai moral bila dapat menajdi hukum universal, yang berlaku objektif; 2) martabat manusia, yaitu tidak boleh menjadikan manusia sebagai alat dalam kondisi apapun, manusia adalah tujuan dari dirinay sendiri; 3) otonomi moral, yaitu kehendak bebas.

Jelas kant memisahkan wilayah sains yang ada dalam alam fenomena disatu sisi dan wilayah moral serta hukum ada sisi lain ada pada alam noumena. Hukum dan moral yang berada pada wilayah noumena juga oleh kant di pisahkan, moral ada pada isi atau semenatra hukum ada pada bentuk. Dengan memeprhatikan pemisahan itu maka dapat di simpulkan bahwa secara umumum objek pengtahaun pada umumnya dan hukum serta moral khusnya dalam perspektif kant berupa dunia fisik, sebagi kebalikan dari alam alam metafisik yang bersumber dari wahyu, atau alam natural,

Bagi Kant hukum merupakan produk dari kehendak bebas manusia yang sama sekali tidak dikaitkan dengan metafisik (iman), dan dan realitas emprtis. Kehendak bebas akal ini akan melahirkan moralitas otonom yakni moralitas yang berangkat dari argumentasi "demi kewajiban" berangkat dari batiniah/hatinurani sebagai kebalikan dari moral heteronom yakni tindakan moral diambil atas dasar argementasi "sesuai kewajiban".

\section{Sumber Hukum Dan Moral}

Hal pertama yang perlu diejalaskan terkait dengan ini adalah bila sains dikonstruksi berdasarkan perpaduan dari hasil sensasi-sensasi panca indera dan di olah oleh rasio, yang melahirkan pengetahuan apriori, persolannya dengan apa hukum dan moral yang hanya dapat dijangkau dengan akal pratis tersebut diostruksi ? untuk mengetahui hal ini maka perlu dipahami uraikan kant tentang yang mendinsting moralitas dan legalitas, otonomi dan heteronomy, imperative kategoris dan imperative hipotesis, demi kewajiban dan sesuai kewajiban, batiniah dan lahiriah. 
Bilai kita cermati pada aspek ini sesungguhnya baik hukum dan moral memiliki cara kerja dan bentuk yang berbeda, yaitu: a: moral disamping menggunakan alat indra dan rasio juga intusi sangat menentukan, pelibatan intuisi inilah yang menajdikan pemikiran moral kant memiliki kemiripan dengan etika islam yaitu "niat", aspek intuis bekerja dalam uraian kant tentang otonomi moral, atau saura hati, dan batiniah, sebagai moral sejati.

Sebaliknya hukum yang dikedepankan adalah bentuk lahiriahnya yang berwujud legalitas, terlepas motifasinya heteronomy, imperative hipotesis, demi kewajiban. Maka disini yang bekerja adalah murni rasio apriori. Dengan demikian pada aspek ini kant dalam bentuk relasi inepeden-dialog.

\section{Wilayah Hukum dan Moral}

Wilayah, pada aspek wialyah hukum dan wilayah moral kant jelas memperlihatkan relasi independen, hal ini dapat dicermati dari pemisahan atas peran akal pratis yang bagi atas is (materi) yang memprosuksi moralitas, dan wialyah ougt/bentuk atau legaslitas. Menurut Kant, Hukum merupakan wilayah Sollen, manusia: bebas, otonom, sederajat, dan rasional, 'hiduplah berdasarkan hukum jika ingin hidup bersama secara damai dan adil, hukum harus obyektif, tidak bias moral/nilai kelompok, hukum tidak dibuat atas dasar petimbanganpertimbangan pragmatis berbasis pengalaman inderawi seperti rasa enak, rasa suka, rasa untung, dan lain sebagainya, hukum merupakan bidang sollen, yakni norma-norma, sesuaikan diri dengan apa yang sudah dibentuk sebagai hukum.

\section{Skema:}

\section{Objek Sains, Moral dan Hukum Menurut Immanuel Kant}

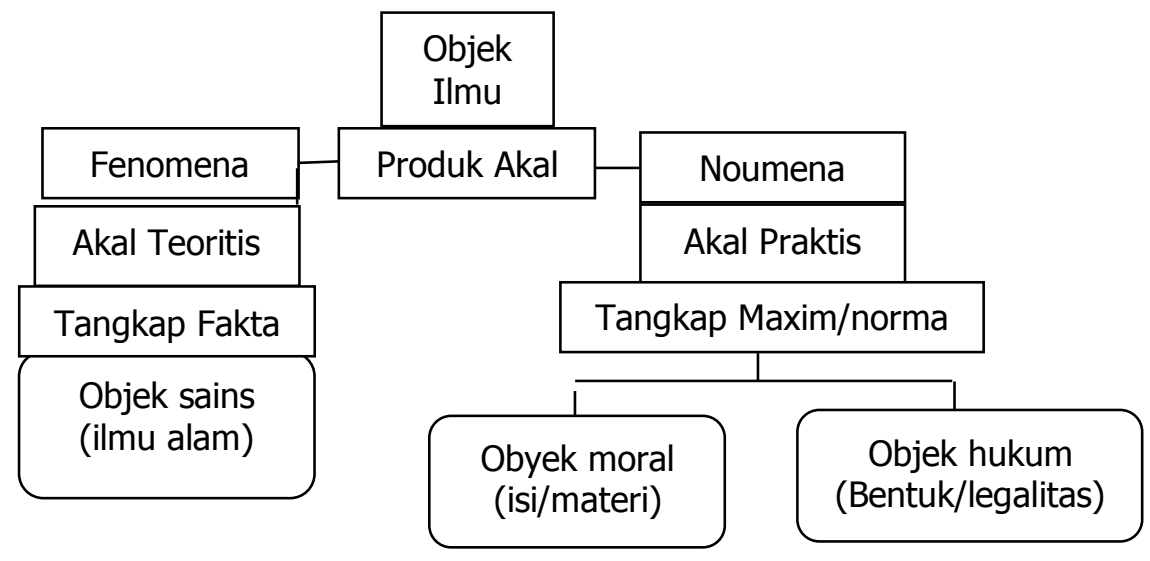


Menurut Kant kewajiban merupakan dasar tindakan moral, dalam grundlegung Kant mengatakan bahwa satu-satunya hal yang baik tanpa kualifikasi atau pengecualian adalah "kehendak baik (guter wille)". demi kewajiban, hanya cinta praktis inilah yang lantas bisa menjadi objek perintah moral. dengan maksud yang sama Kant mengatakan bahwa bertindak berdasarkan maksim formal, murni dan a priori, mutlak, tidak partikular melainkan Universal. ${ }^{13}$

Moralitas otonom sebagai bentuk moralitas tertinggi, sebagai prinsip hukum tertinggi dan manusia sebagai tujuan, bertitik tolak dari batiniah/rohani lewat akal budi yang bebas, melahirkan dua bentuk kaidah, yakni kaidah maxime yang besifat subjektif dan kaidah obejktif. Pada tahap kaidah subjektif belum bisa dikatakan sebagai bentuk moralitas tertinggi atau belum dapat melahirkan perintah tidak bersyarat atau imperative kategoris, karena pada tahap ini manusia mengambil tindakan masih dipengaruhi oleh kecenderugan-kecenderungan lain. Untuk sampai pada tahapan imperative kategoris maka harus ada norma objektif, norma ini obejktif pada dirinya sendiri karena dilakukan demi kewajiban tadi, tanpa motif untung rugi, senang tidak senang, dan ia lepas dari moral heteronom tadi.

Pada tahap moralitas otonom lewat akal budi yang bebas yang meproduksi kaidah objektiflah yang dapat mewujudkan kaidah imperative kategoris, sebagai kebailkan dari kaidah imperative hipotesis, kaidah hipotesis diproduksi oleh moralitas heteronom, sebaliknya kaidah imperative kategoris diprosuksi oleh moralitas otonom.

Ketika sampai pada level imperative kategoris, maka ada dua kemungkinan bentuk yang muncul, pertama bentuk moralitas dan kedua berbentuk legalitas, imperative kategoris yang berbentuk moralitas manakala dikakukan "demi kewajiban/batiniah/hati nurani" sebaliknya apabila dilakukan "demikian kewajiban/lahirian" maka akan berbentuk legalitas semata.

Moralitas bagi Kant adalah kesesuaian atau tidak kesesuaian ini pada dirinya sendiri belum bernilai moral, sebab dorongan batin sama sekali tidak diperhatikan. nilai moral baru diperoleh dalam moralitas. yang dimakud Kant dengan Moralitas adalah kesesuaian sikap dan perbuatan kita dengan norma atau hukum batiniah kita, yakni apa yang kita pandang sebagai kewajiban kita. moralitas akan tercapai apabila kita menaati hukum lahiriah bukan lantaran hal itu membawa akibat yang menguntungkan kita atau lantaran takut pada kuasa sang pemberi hukum, melainkan kita sendiri menyadari bahwa hukum itu merupakan kewajiban kita $^{14}$.

\footnotetext{
${ }^{13}$ S.P. Lili Tjahjadi, Hukum Moral: Ajaran Immanuel Kant Tentang Etika dan Imperatif Kategoris, (Yogyakarta: Kanisius, 1991), hlm. 50-53.

${ }^{14}$ S.P. Lili Tjahjadi, Hukum Moral...ibid, hlm. 47.
} 
"Moralitas heterenom adalah sikap dimana kewajiban ditaati dan dilaksanakan bukan karena kewajiban itu sendiri, melainkan karena sesuatu yang berasal dari luar kehendak sipelaku itu sendiri. adapun moralitas otonom merupakan kesadaran manusia akan kewajibannya yang ia taati sebagai sesuatu kehendakinya sendiri karena diyakini sebagai baik atau mempunyai budi yang baik. budi praktis menurut Kant ada dua, yaitu: 1. Maksim, maksim (maxime) merupakan prinsip yang berlaku secara subjektif, yang menjadikan seseorang menganggapnya sebagai pedoman untuk bertindak. 2. Kaidah Objektif, prinsip atau kaidah objektif adalah prinsip yang memberi patokan bagaimana orang harus bertindak, semisal undang-udang atau hukum. lebih lanjut Menurut Kant ada 2 macam imperatif, yaitu: 1. Imperatif hipotesis adalah perintah bersyarat, berlaku secara umum (suatu tindakan yang diperlukan sebagai sarana atau syarat untuk mencapai sesuatu yang lain). Imperatif Kategoris adalah perintah mutlak. disini kehendak dan hukum adalah satu (Budi Praktis yang murni). Imperatif Kategoris inilah yang dipandang Kant sebagai azas kesusilaan yang transendental ${ }^{15}$."

${ }^{15}$ S.P. Lili Tjahjadi, Hukum Moral...ibid, hlm. 48-50. 
Skema:

Imperatif Kategori Immanuel Kant

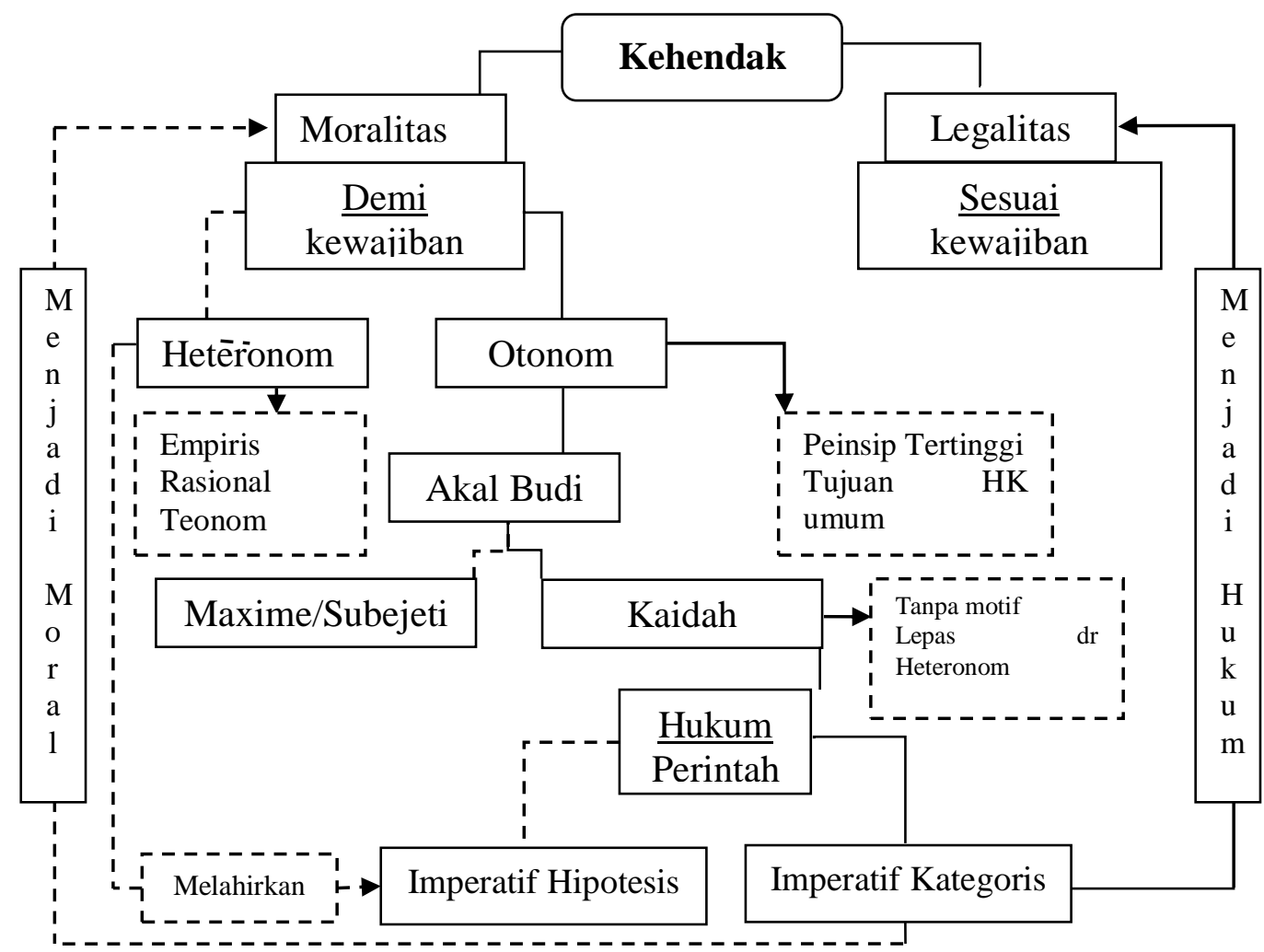

Imperatif kategoris Immanuel Kant disebut etika deontologis, ia berbicara otonomi moral, Moralitas itu seperti imperatif kategoris yakni perintah tidak bersyarat lawannya adalah perintah hipotesis, otonomi lawannya heteronom, Heteronom adalah megikuti hukum yang dipasang orang lain dan tidak disadari sendiri sebagai hukum, Kant menyatakan, kita masing-masing harus mengikuti apa yang menjadi kewajiban tanpa kecuali. Kriteria moral dalam imperatif kategoris Kant adalah keberlakuan umum/universalisasikan sebuah prinsip atau hukum tersebut. Kant membedakan moralitas dan legalitas, Legalitas adalah perbuatan baik yang dibuat tidak untuk memenuhi hukum moral, sebaliknya moralitas adalah perbuatan sesuai dengan suara hati, atau perbuatan moral.

\section{Tujuan Hukum dan Moral}

Pada aspek ini pemikiran kant menunjukan relasi independen pula, dimana kant berusaha membangun pemikrian hukum yang berbentuk imperative kategoris, yang berujung pada penguatan sebagai bentuk atau 
legalitas, yang pada akhirnya perilaku seseorang tiak harus denial idari motifasi iman, dan batinnya, tetapi perialku seseorang diukur dari bentuk lahiriahnya, walau pada konteks ini bisa saja isi norma itu sudah adil, akan tetapi juag yang paling mendcolok dari tujaun hukum menurut dalam pemikiran kant adalah bentuk kepastiannya, yaitu noram umum yang berlaku objektif, yang menjunjung matrabat manusia

Sementara moralitas menentukan tujuan untuk meraih kebaikan virtue dengan happiness, virtue bersifat unconditioned, tidak bersyarat, otonom, kategoris, dan universal. Sedangkan happiness bersifat conditioned, bersyarat, heteronom, hepotesis, dan particular. Hubunagn antara virtue dengan happiness ada hubungan sebab akibat, di mana virtue berfungsi sebagai landasan, sedangakn happiness merupakan konsekuensi yang menyertai virtue. Hal ini berarti bahwa tanda ada dorongan dalam diri manusia untuk meraih virtue, maka happiness tidak memiliki landasan yang kokoh dalam dirinya. ${ }^{16}$

Bagi Kant, dengan pemahaman terhadap virtue sebagai tujuan akhir dari pure practical reason, maka norma moral mengarah pada agama. Norma moral mengarah pada pengakuan terhadap kewajibankewajiban sebagai perintah Tuhan. Tuhan adalah Yang Maha Sempurna secara moral, sehingga kehendak dan perintah-Nya juga sempurna secara moral. Dengan adanya penyelarasan ini, akan diakuilah kewajiban terhadap perintah Tuhan. Inilah yang oleh Kant diakui sebagai awal mula agama. Pandangan ini membawa implikasi bahwa moralitaslah yang mengarahkan manusia pada agama, sebab moralitas lebih dahulu ada daripada agama. Pandangan Kant tentang agama banyak dipengaruhi oleh keyakinannya akan keterbatasan akal teoritis (pure reason) dalam mengungkap misteri, Tuhan, dan alam ghaib (metarasional), bila seorang bersikukuh untuk menggunakan pure reason dalam memahami, misalnya, wahyu atau teks agama (seperti adanya Tuhan), maka akan terjebak pada "paralogisme". Oleh sebab itu, bagi Kant memahami teks kitab suci harus dilihat urgensinya secara moral. Sebab, agama tidak akan ada gunanya bila tidak dapat bernilai moral. Untuk mempertegas pandangannya tentang kaitan agama dengan moral, Kant memperkenalkan apa yang disebut dengan agama sejati (true religion), yaitu agama yang menyatakan di dalam kewajiban harus memandang Tuhan sebagai Sang Pemberi hukum universal yang harus dihormati. Menghormati Tuhan berarti telah menaati hukum moral, yakni bertindak sesuai kewajiban sebagai perintah-Nya. ${ }^{17}$

\footnotetext{
${ }^{16}$ https://grahafilsafat. wordpress.com/2015/04/13/konsep-etika-modern-immanuel-kant2/ diakses 10 Juli 2017, pukul 14.00 Wib.

${ }_{17}$ https: //grahafilsafat.wordpress.com/2015/04/13/konsep-etika-modern-immanuel-kant2/ diakses 10 Juli 2017, pukul 14.00 Wib.
} 


\section{Skema :}

Relasi Hukum dan Moral Model Immanuel Kant

\begin{tabular}{|c|c|c|c|c|}
\hline Aspek & Hukum & Moral & $\begin{array}{l}\text { Relasi } \\
\text { Khusus }\end{array}$ & $\begin{array}{l}\text { Relasi } \\
\text { Umum }\end{array}$ \\
\hline Objek & $\begin{array}{l}\text { Kaidah } \\
\text { Objektif }\end{array}$ & $\begin{array}{l}\text { Maxim- } \\
\text { Maxim }\end{array}$ & $\begin{array}{l}\text { Independen- } \\
\text { Dialog }\end{array}$ & \multirow{4}{*}{$\begin{array}{l}\text { Independen } \\
\text { Dialog }\end{array}$} \\
\hline Sumber & Indera-Rasio & $\begin{array}{l}\text { Indera-Rasio- } \\
\text { Intuisi }\end{array}$ & $\begin{array}{l}\text { Independen- } \\
\text { Dialog }\end{array}$ & \\
\hline Wilayah & $\begin{array}{l}\text { Bentuk/Legalit } \\
\text { as }\end{array}$ & Isi/ Materi & $\begin{array}{l}\text { Independen- } \\
\text { Dialog }\end{array}$ & \\
\hline Tujuan & Kepastian & $\begin{array}{l}\text { Summum } \\
\text { Bonum }\end{array}$ & $\begin{array}{l}\text { Independen- } \\
\text { Dialog }\end{array}$ & \\
\hline
\end{tabular}

\section{PENUTUP}

Pemisahan oleh Immanuel Kant tentang wilayah fenomena sebagai wilayah atau objek ilmu alam atau sains, dan wilayah noumena sebagai wilayah atau objek hukum, moral, membawa implikasi yang luas, bahkan Kant sendiri menyatakannya sebagai upayanya melakukan revolusi copernicun, pemikiran ini sangat berpengaruh sebagai pijakan pemikiran positivisme hukum (terutama dalam pemisahan is dan ought), yang dianggap sebagai pemberi sumbangsih atas terpurukan dunia hukum, sebab menyingkirkan aspek transedental dalam konstruksi hukum, termasuk juga moral. Bila ditelusuri lebih mendalam sesunggunya pemikiran Immanuel Kant, salah dipahami oleh para pengemban teoritis positivisme hukum, sebab kant tidak menjauhkan aspek-aspek transenden dan juga moral sebagaiaman yang dipahami kaum positivisme hukum dewasa ini, sebab relasi hukum dan moral dalam perspektif Immanuel kant walau kant memisahkannya akan tetapi dalam posisi sejajar dan berdialog, hal ini dapt dijelaskan dari pemisahakn objek, sumber, metodelogi dan juga tujuan, yang sesungguhnya tidak berdiri sendirisendiri. 


\section{DAFTAR PUSTAKA}

T.M. Soerjanto Poespowardojo \& Alexander Sera, Filsafat Ilmu Pengetahuan: Hakikat Pengetahuan, Kritik Terhadap Visi

Positivisme Logis Serta Implikasinya, (Jakarta: Kompas, 2015).

Jurgen Harbemas, Rasio dan rasionalitas masyarakat, terjemahan dari

Theorie Des Kommunikative handles oleh Nurhadi, (Bantul: Kreasi

Wacana, 2012).

Adam Podgorecki \& Oligiati (eds), 1996.

Phillepe Nonet \&phillip Selznick, Law and Society in transition : toward tanggapananive, London: Harper n Row Publisher.

Yovita A. Mangesti, Bernard L. Tanya, Moralitas Hukum,( Yogyakarta, Genta Publishing, 2014).

Shaomin Li, Ilan Alon dan Jun Wu, Corruption May Worsen In Democratizing Economies: But Don't Let It Erode Our Faith In Democracy, Modern China Studies: Norfolk, Vol. 24, Issue. 2 (2017): 184-188.

Satjipto Rahardjo, Pendidikan Hukum Sebagai Pendidikan Manusia: Kaitannya dengan Profesi Hukum dan Pemabangunan Hukum Nasional, (Yogyakarta: Genta Publishing, 2009), hlm. 135.

Khudzaifah Dimyati, Pemikran Hukum: Sebuah Konstruksi Epistomologi dalam Pemikiran Berbasis Nilai Budaya Hukum Indonesia, (Yogyakarta: Genta Publishing, 2014).

Absori, dkk, Transedensi Hukum: Prosepek dan Implemetasi, Yogyakarta: Genta Publishing dan Program Doktor (S3) Ilmu Hukum SPs UM Surakarta, 2017).

Soejono Soekanto, Pengantar penelitian hukum, (Jakarta: Universitas Indonesia, 1981

Soetandyo Wignjosoebroto Soetandyo W, Penelitian Hukum: Sebuah Tipologi, Majalah Masyarakat Indonesia Tahun Ke1, No, 1974, hlm. 4. Lihat,

Soetandyo Wignjosoebroto, Hukum: Paradigma, Metode dan Dinamikan Maslahnya, Jakarta: Huma-Elsam, 2002

Soetandyo Wignjosoebroto, Hukum: Paradigma, Metode Dan Dinamikan Maslahnya, (Jakarta: Huma-Elsam, 2002), hlm. 146-147.

Immanuel Kant, Critique of Practical Reason (Yogyakarta: Pustaka Pelajar, 2005).

S.P. Lili Tjahjadi, Hukum Moral: Ajaran Immanuel Kant Tentang Etika dan Imperatif Kategoris, (Yogyakarta: Kanisius, 1991).

https: / grahafilsafat.wordpress.com/2015/04/13/konsep-etika-modernimmanuel-kant-2/ diakses 10 Juli 2017, pukul 14.00 Wib. 